\title{
Morphological evolution of the Maipo River in central Chile: Influence of in-stream gravel mining
}

\author{
Felipe Arróspide ${ }^{\mathrm{a}, \mathrm{b}}$, Luca Mao ${ }^{\mathrm{c}, \mathrm{b}}$, Cristián Escauriaza ${ }^{\mathrm{a}, \mathrm{b}, *}$ \\ ${ }^{a}$ Departamento de Ingeniería Hidráulica y Ambiental, Pontificia Universidad Católica de \\ Chile. Av. Vicuña Mackenna 4860, 7820436, Santiago, Chile. \\ ${ }^{b}$ Centro de Investigación para la Gestión Integrada de Desastres Naturales (CIGIDEN), \\ Chile. \\ ${ }^{c}$ Departamento de Ecosistemas y Medio Ambiente, Pontificia Universidad Católica de \\ Chile. Av. Vicuña Mackenna 4860, 7820436, Santiago, Chile.
}

\begin{abstract}
In-stream gravel mining is one of the most important causes of channel degradation in South America, specifically in rivers located near large metropolitan areas with rapidly growing cities, where no river management strategies exist. In the western region of the continent, many of these rivers belong to Andean systems, in which significant parts of the watersheds are located in mountain areas at high altitude, with considerable seasonal rainfall variability, and steep channel slopes. In these rivers, gravel mining has produced significant incision of the channels with serious physical and ecological consequences, affecting habitats, modifying the supply and transport of sediments, and amplifying the risk to infrastructure in and around the channel during floods. In spite of the degraded conditions of many channels, no quantitative studies of the geomorphic impacts of gravel mining have been carried out in the region, mostly due to the insufficient and sparse data available. In this investigation we perform an analysis of the morphodynamic evolution in a section of the Maipo River, in the Metropolitan Region of Santiago, Chile. This river is the economically most important in the country, as it provides drinking and irrigation water to urban and rural areas, is utilized by the energy generation industry, and runs along and below critical infrastructure. We have collected and analyzed data
\end{abstract}

\footnotetext{
* Corresponding author
} 
from 1954 to 2015, during which the city population increased by more than 5 million inhabitants whose presence accelerated land use changes. The analysis shows a rapid morphological evolution of the channel where in 31 years there are sections that exhibit an incision of up to $20 \mathrm{~m}$, an increase of the area affected by gravel mining from 86.62 to 368.13 hectares, and a net erosion volume of 39.4 millions of $\mathrm{m}^{3}$. This work yields quantitative information on the consequences of gravel mining in the Maipo River, providing the necessary data to develop an integrated strategy to define management and restoration actions for this and other similar Andean rivers.

\section{Introduction}

Human activities can impact significantly the morphology of rivers by modifying the supply, transport, and storage of sediments in the watershed. These alterations to the sediment regime not only affect the morphological evolution 5 of the river channel, but can also endanger the infrastructure and ecological integrity of the streams, by disturbing the stability of the channels, increasing bank erosion, and modifying the aquatic habitats in the river (Kondolf, 1994b; Surian and Rinaldi, 2003; Comiti et al., 2011).

In-stream gravel mining is one of the most detrimental activities in the evolution of the river morphology, and has significant consequences over spatial and time scales, from tens of years (Petit et al., 1996; Rinaldi et al., 2005; Arnaud et al., 2015) to hundreds of years (Surian and Rinaldi, 2003; Wyżga et al., 2016; Comiti et al., 2011). Effects of gravel mining have been widely studied in Europe and North America (Kondolf, 1994a,b; Gaillot and Piégay, 1999;

15 Martín-Vide et al., 2010; Comiti et al., 2011; Ziliani and Surian, 2012). In Italy and Spain, for example, gravel mining has been identified as the main driver in river adjustments (Batalla, 2003; Surian et al., 2009; Scorpio and Rosskopf, 2016), which acts together with additional processes linked to channelization and afforestation, along with the presence of dams, that might also have greater 20 predominance on the channel evolution (Kondolf et al., 2007; Warner, 2012). 
In France, gravel mining in coastal rivers has produced beach erosion (Gaillot and Piégay, 1999), and dams have had a significant effect on river morphology, by favoring sand harvesting and yielding water table and riverbed lowering as a direct effects (Petit et al., 1996). In Poland, extraction of coarse particles in the river bed favored the entrainment of finer material (Zawiejska et al., 2015) and channel incision had different effect on rivers depending on their stream power and also with different effects at the local or regional scale (Wyżga et al., 2016).

Although effects of sediment mining on rivers may be different by depending on the degree of human intervention, it is clear that there is a strong temporal relationship with rivers being highly responsive to human impact and even showing the ocurrence of "inertial" effects. (Surian and Rinaldi, 2003; Rivas et al., 2006; Martín-Vide et al., 2010; Belletti et al., 2016), and the capability to recover when human activities stopped at the river (Comiti et al., 2011; Scorpio and Rosskopf, 2016).

To study these effects and understand the current and long term conditions, a historical analysis on the river morphology can be performed to evaluate quantitatively the evolution of the channel. Planform analysis has been performed throughout the years by the use of maps and air photographs (Downward et al., 1994; Gurnell et al., 1994; Hughes et al., 2006; Zanoni et al., 2008; Comiti et al., 40 2011; Little et al., 2013; Arnaud et al., 2015). These remote sensing techniques have proven to be quite accurate measuring landscape properties (Mertes, 2002). Studies of morphological changes have examined the adjustment of the active corridor width and land cover (Zanoni et al., 2008; Comiti et al., 2011), active channels (Comiti et al., 2011; Arnaud et al., 2015), and vegetation boundaries

45 (Comiti et al., 2011; Arnaud et al., 2015). Cross section topographic sampling and analysis has also been used to estimate sediment budget, incision or deposition (Gob et al., 2005; Arnaud et al., 2015). Technological improvements have allowed the use of Digital Elevation Models (DEMs) to directly calculate sediment budgets (Lane et al., 2003; Wheaton et al., 2010; Milan et al., 2011;

50 James et al., 2012). These DEMs are constructed upon digital photogrammetry, laser altimetry and image processing to provide a complement for cross section 
analysis since the comparison of DEMs requires an error filter (Milan et al., 2011).

Rivers in Europe have shown a common pattern of evolution of their morphology (Surian and Rinaldi, 2003, 2004; Surian et al., 2009; Scorpio et al., 2015; Scorpio and Rosskopf, 2016) in the last 150-200 years, with incision and narrowing of the channels as the main processes at the initial stages from the early nineteenth century, to the 1980s-1990s, being the most intense period between the 1950 s to $1990 \mathrm{~s}$, followed by a widening and sedimentation phase afterwards.

It has been shown that sediment mining and dam construction had a main role in the incision and narrowing phases with an intense effect at the beginning and then becoming slower towards asymptotic state.

The incision process has been observed to be closely tied with gravel mining and vice-versa (Kondolf, 1997), with average values of river bed incision in 65 the order of 4 to $10 \mathrm{~m}$ (Surian and Rinaldi, 2003; Wyżga, 2007) and in some cases, incision has been persistent even though mining operations have stopped (Surian et al., 2009; Martín-Vide et al., 2010; Comiti et al., 2011), evidencing the "inertial" effects. Narrowing has been observed in the active channel for braided rivers to an order of 50\% (Surian and Rinaldi, 2003), changing the pattern to a wandering one. However, it has been observed that once the gravel mining stops, the active channel starts widening back again (Comiti et al., 2011). Although most cases have experienced incision alongside narrowing, there have been exceptions where incision and widening have both taken place concurrently (Bollati et al., 2014).

In this context, South American studies on river morphology and its evolution through time are currently under development, with research performed in Argentina where the intensity of changes in rivers are driven mainly by the combination of technology, wealth, and growing urban population (Rivas et al., 2006), however no additional studies have been performed In addition to the accelerated urban expansion and changes in land-use and cover, many rivers in developing countries are also affected by in-stream gravel mining, which is one of the most important disturbances, producing rapid incision and narrowing of the 
channels. In South America, most of the urban growth has occurred in mountainous regions or the piedmont near the Andes, where the rivers have been impacted by (besides gravel mining) the construction of dams, power-plants, water diversion structures, and deforestation. Such is the case of Chile, where the local scientific society has already noted the need for a hydromophological approach on river management (Andreoli et al., 2012) and methodologies for optimization of exploitation of resources have been proposed (Godoy et al., 2010), however there have been no quantitative studies, and most scientific evidence is available locally, trying to adapt analyses performed in other latitudes to the local context.

Our investigation is the first of its kind in South America to provide quantitative measurements of morphological impacts due to in-stream human activity, being gravel mining the most important. Our goal is that this paper will become a first step towards increasing attention on Chilean and South American fluvial systems in an integrated management focus.

This paper is organized as follows. In section 2 a brief description of the area of study, the Maipo watershed in central Chile is presented, including the sub-reach where most of the gravel-mining activities have concentrated. The methods employed in this investigation, including the available data, are explained in section 3. In section 4, evolution of the Maipo River through the calculation of morphological parameters is reported. In section 5 the relation among these parameters and the consequences of in-stream gravel mining is discussed. Finally, the conclusions summarize the findings of this investigation and outline topics for future research.

\section{Study Area}

The study was carried out in the Maipo River basin, draining an area of $15,380 \mathrm{~km}^{2}$, most of it located within the Metropolitan Region in central Chile, between $32^{\circ} 55^{\prime}-34^{\circ} 15^{\prime} \mathrm{S}$ and $69^{\circ} 46^{\prime}-71^{\circ} 43^{\prime} \mathrm{W}$ (Fig. 1). The river headwaters lie at the foothills of the Maipo Volcano (3,135 m a.s.l.), in the Andes mountain 
range. Most drinking water and irrigation supply in the region is provided by the Maipo River, approximately $70 \%$ and $90 \%$, respectively.

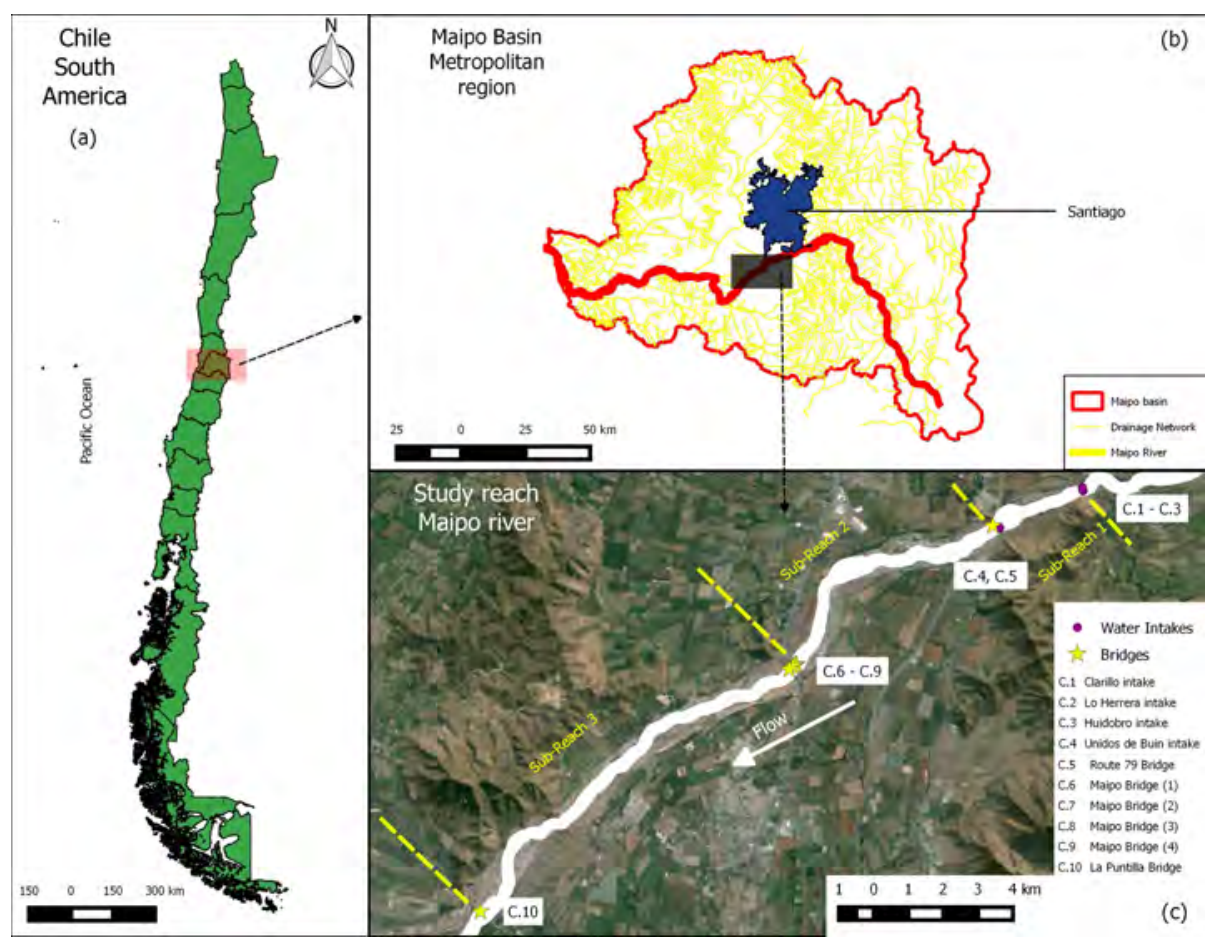

Figure 1: Location of analyzed reach in central Chile (1a). The Maipo River flows from east to west and is located directly south of Santiago city (1b) in the Maipo basin. The river at the study reach flows NE-SW and it is approximately $22 \mathrm{~km}$ long, with several structures installed (water intakes and bridges) (1c). The discretization of the study reach is also presented.

The climate is mediterranean with an extended dry season, although recent studies show a warming trend in the central valleys of Chile (Cortés et al., 2011). The dry season starts in April and ends in October, which corresponds to autumn and winter. During spring and summer, the snow melting in the Andes raises the discharge in the Maipo River and its tributaries, making the river specially sensitive and dependent on snowmelt for irrigation purposes (Cortés et al., 2011). Historical monthly average flow is $104 \mathrm{~m}^{3} / \mathrm{s}$, while the snowmelt season (October to March) average discharge is $151 \mathrm{~m}^{3} / \mathrm{s}$ and during winter 
(April to September) has an average month discharge of $57 \mathrm{~m}^{3} / \mathrm{s}$, showing an approximate of $50 \%$ variability. Figure 2 shows the day average river discharge.

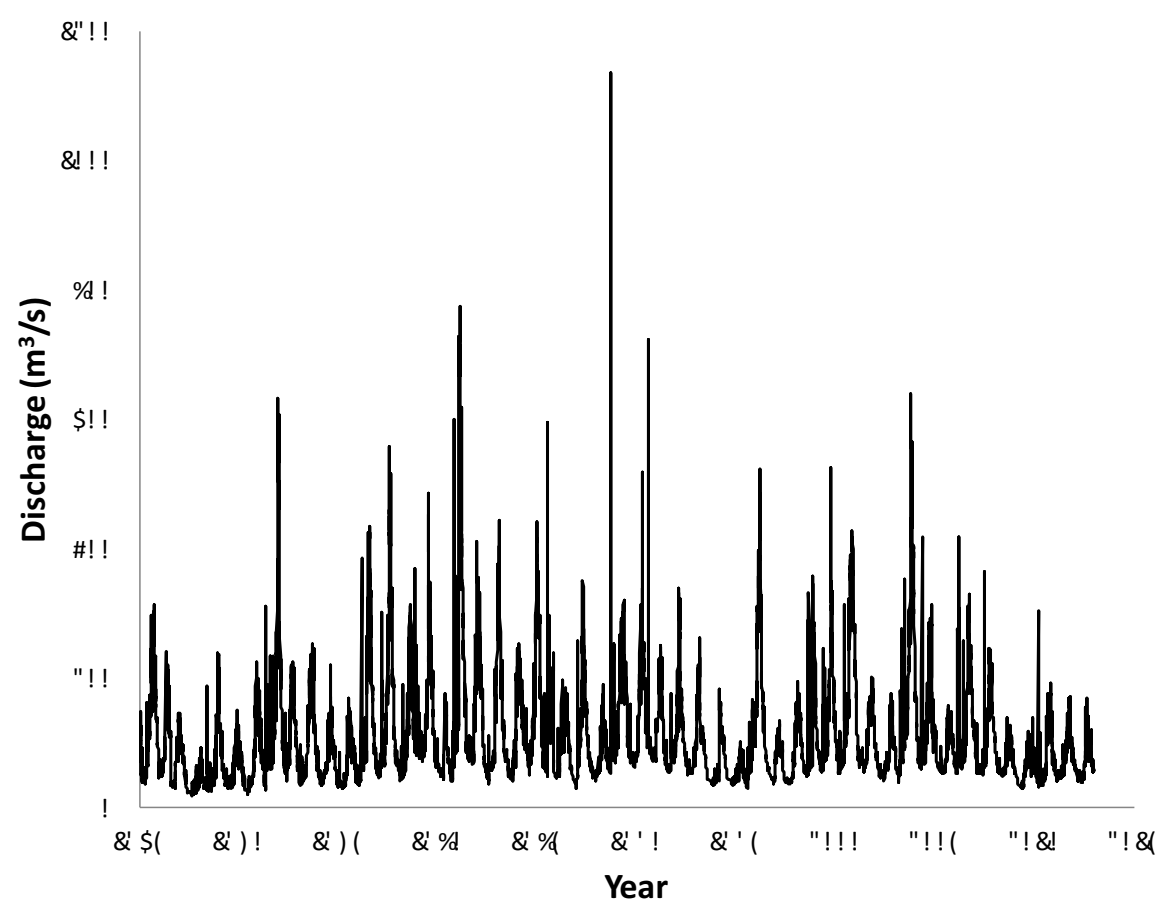

Figure 2: River discharge time series for the Maipo River.

The Maipo River is a key element for the basin and the city of Santiago, since it has been directly involved in major events that have caused significant effects on the cities and local towns, mainly debris flows, and water supply interruption for millions of inhabitants from 2008 to 2017 (e.g. Sernageomin, 2016). The water supply system is subject to a high risk of failure, due to increasing turbidity caused by warm storm in the Andes region. Warm storms raise the freezing level in the ravines and foothils of the Andes mountain range increasing the water volume available causing flooding, landslides, and debris flows if precipitation is intense or prolonged (Garreaud, 2013). Every time these phenomena take place, drinking water supply is completely halted for most of 

depending on the intensity of these warm storms.

This investigation focuses on a specific reach of the Maipo River, as shown in Fig. 1b, which has been selected as it expresses the largest amount (concentration) of in-stream gravel mining activities. In this part of the channel, the Maipo River flows in a west-southwest direction, such that the river banks are defined as the north (right) bank and the south (left) bank. The study reach is approximately $22.1 \mathrm{~km}$ long, with an average slope of 0.009 and an approximate stream power value of $5 \mathrm{~kW} / \mathrm{m}$ and $13 \mathrm{~kW} / \mathrm{m}$ in the low and high season respectively.

The reach is characterized by the presence of important infrastructures that have been built over the last 60 years. In the upstream section of the reach, there are three water intakes (features C.1 to C.3 in Fig. 1c). The largest, which is indicated as (C.1), comprises a sluice gate whose default operation status is to be closed towards the main channel, diverting water to the irrigation channels indicated as (C.2) and (C.3). At a distance of $3 \mathrm{~km}$ downstream from this location, there is a gate (C.4) that diverts flow towards another irrigation channel. In this section there are two bridges across the Maipo River, being the Route 79 bridge (feature C.5) the most important between them.

Approximately $8 \mathrm{~km}$ downstream from Route 79 bridge, there are four more bridges crossing the river (features C.6 to C.9 in Fig. 1C). These bridges are part of the Route 5 river crossings, the most important road in Chile, which connects the country longitudinally from the far north to south. At $8 \mathrm{~km}$ downstream of Route 5 bridges, there is a small canyon where the river cross-section is narrowed from $600 \mathrm{~m}$ wide to $150 \mathrm{~m}$; this feature is located between two hills, Puntilla Lonquén and Cerillos la Finca.

As a result of this layout, all available water is taken from the river to the irrigation channels as much as the water stocks allow it for the different owners. If there is any surplus water available, it is given back to the river via intakes (C.1) and (C.4), known as Clarillo and Unidos de Buin intakes respectively, 
itself since no flow gauges are installed downstream intake (C.1). Additionally, local sources state that surplus water is actually rare and there is a lack of management and surveillance when floods occur since all associations focus on their own channels and close their gates. Due to the almost complete water allocation, the study reach is virtually dry for most of the time, leaving little to none sediment recharge possibilities. This is due to the fact that several gravel mining sites and storing facilities are present along the study reach. The authority to issue permits for gravel mining falls to local city halls as stated by Chilean law.

\section{Materials and Methods}

In this investigation, planform and elevation morphological changes are assessed using available aerial photos and topographic surveys covering the last 60 years. Planform changes are determined using aerial photographs, satellite images, and public maps, while elevation changes are measured using topographic data and surface contours obtained from different methodologies over the years.

According to the spatial distribution of the anthropic intervention in the river, the study reach was divided into three sub-reaches. The first sub-reach extends from the upstream boundary (feature C.1 in Fig. 1c), to the Route 79 bridge (feature C.5 in Fig. 1c). The second sub-reach extends from the Route 79 bridge to the Route 5 bridge (feature C.9 in Fig. 1c). Finally the third sub-reach extends from the Route 5 bridge to the La Puntilla bridge (feature C.10 in Fig. 1c), the downstream boundary of the study reach.

The study reach was segmented studied in the longitudinal and transverse directions, with cross-sections marked on the channel. The original data of the reach and river banks was obtained from aerial photographs taken in 1954 that were digitized, creating three alignments following the centerline between the river banks. Each alignment corresponds to a sub-reach, where sample lines were plotted every $100 \mathrm{~m}$ for planform analysis, and every $200 \mathrm{~m}$ to carry out the study of changes on the topography. A special refinement, however, 
detailed data was measured and reported every $20 \mathrm{~m}$.

\subsection{Land cover and morphological planimetric changes using maps, air pho-} tographs, and satellite images

The main sources of information surveyed were aerial photographs from years

200

was performed in the vicinity of Route 79 and Route 5 bridges, where highly 54, 1992, 1994, 1997 and 2008 provided by the Aerial Photogrammetry Service of the Chilean Air Force (SAF), and the Geographical Institute of the Chilean Army (IGM), along with Google Earth imagery from year 2015. A topography map from 1980 was also used to complement the analysis.

SAF aerial photographs were scanned with 600 DPI resolution and georeferenced using approximately 15 ground control points for each photo such as street intersections, building corners, and bridge columns (Gurnell et al., 1994), and registered to a common base using QGIS 2.8 software. IGM photographs from 1954, on the other hand, were already provided on digital format. A total of 12 control points were used for each photograph, and Google Earth imagery was also registered to the same mapping base using from 10 to 20 points using

Helmert transformation with minimum error. Several screenshots were taken to achieve the best resolution possible for feature identification.

The map from 1980 was issued under a PSAD56 coordinate system, which was re-projected to the WGS84 19S system for digitizing, using map grid intersection points as control points under the QGIS software environment. This re-projection technique has been used to achieve greater accuracy as described by Gurnell et al. (1994). Thin plate spline, which is a second order radial basis function, and polynomial interpolation functions were used for georeferencing.

Finally, aerial low altitude ortho-rectified photographs were taken using an Unmanned Aerial Vehicle (UAV), to improve the resolution near the Route 5 and Route 79 bridges, covering over 90 hectares of each zone. These photographs were also georeferenced to the QGIS database as the UAV carried a GPS receiver. The UAV flights provided high resolution images, with a ground sample distance of $2.83 \mathrm{~cm}$. Table 1 shows a summary of resolutions and image scales 
listed for all sources. All of the sources mentioned above allowed to identify several features such as river banks, irrigation channel intakes, islands, active channels, and bridges.

Table 1: List of data sources used on this study

\begin{tabular}{c|c|c|c|c|c} 
Image Series & Type of image & Source & Year & Scale/Altitude/Resolution & Grayscale/Color \\
\hline 1 & Air photo & IGM & 1954 & $1: 50,000$ & Grayscale \\
2 & Topography map & IGM & 1980 & $1: 20,000$ & Black \& White \\
3 & Air photo & SAF & 1992 & $1: 20,000$ & Grayscale \\
4 & Air photo & SAF & 1994 & $1: 20,000$ & Grayscale \\
5 & Air photo & SAF & 1997 & $1: 70,000$ & Grayscale \\
6 & Air photo & SAF & 2008 & $1: 20,000$ & Color \\
7 & Satellite Image & Google Earth & 2015 & $1: 2500$ & Color \\
8 & UAV Air photo & This study & 2015 & $85.5 \mathrm{~m} ., 2.83 \mathrm{GSD}$ & Color
\end{tabular}

\subsubsection{Morphological analysis}

For years 1954, 1980, 1992, 2008 and 2015, the sinuosity of the channel was calculated, using the parameter of Friend and Sinha (1993), which corresponds to a modification of the classical sinuosity defined by Leopold and Wolman (1957), to fit multi-channel situations. This parameter is defined as follows,

$$
P=\frac{L_{c \max }}{L_{R}}
$$

where $P$ is the sinuosity, and $L_{c \max }$ and $L_{R}$ correspond to the mid-channel length of the widest channel, and the linear distance measured with a straight line between the end points of the reach, respectively. The braiding index (BI), on the other hand, is taken as the average number of parallel channels every $100 \mathrm{~m}$. Control points are plotted below every $100 \mathrm{~m}$, through the centerline of the widest channel when parallel channels are present.

The 1954 set of photographs allowed the identification of active channel, islands and river banks. This set was used as a base for historical comparison of the channel. The active channel was marked in the QGIS database as a 
polyline, while the islands and bars were marked using polygons. Gravel mining sites could not be identified due to the small scale of the photograph set $(1: 50,000)$, but the operations were minimal at the time. The 1980 historical map allowed us to identify the river banks, along with irrigation channel intakes and outlets. Islands and presence of sediment deposits are also identified, with an approximate total area covered by these features of 120.1 hectares.

From the 1992 and 1994 photographs, river banks, active channels, islands, and gravel mining sites are identified. All these features are marked with polygons and polylines in the QGIS database. The 1997 photo set was disregarded because of its scale $(1: 70,000)$, as it was not possible to identify any features except for the river banks. The 2008 full color photograph set allowed identifying river banks, active channels, islands, and gravel mining activities. The same features were also available for the 2015 set.

Human intervention on the river such as gravel extraction and storage, sediment processing plants, and construction sites, are features than can be clearly identified because of their precise shapes (i.e., excavators, or backhoes machinery). Fig. 3 shows some of the most important anthropic activities introduced into the river channel. 


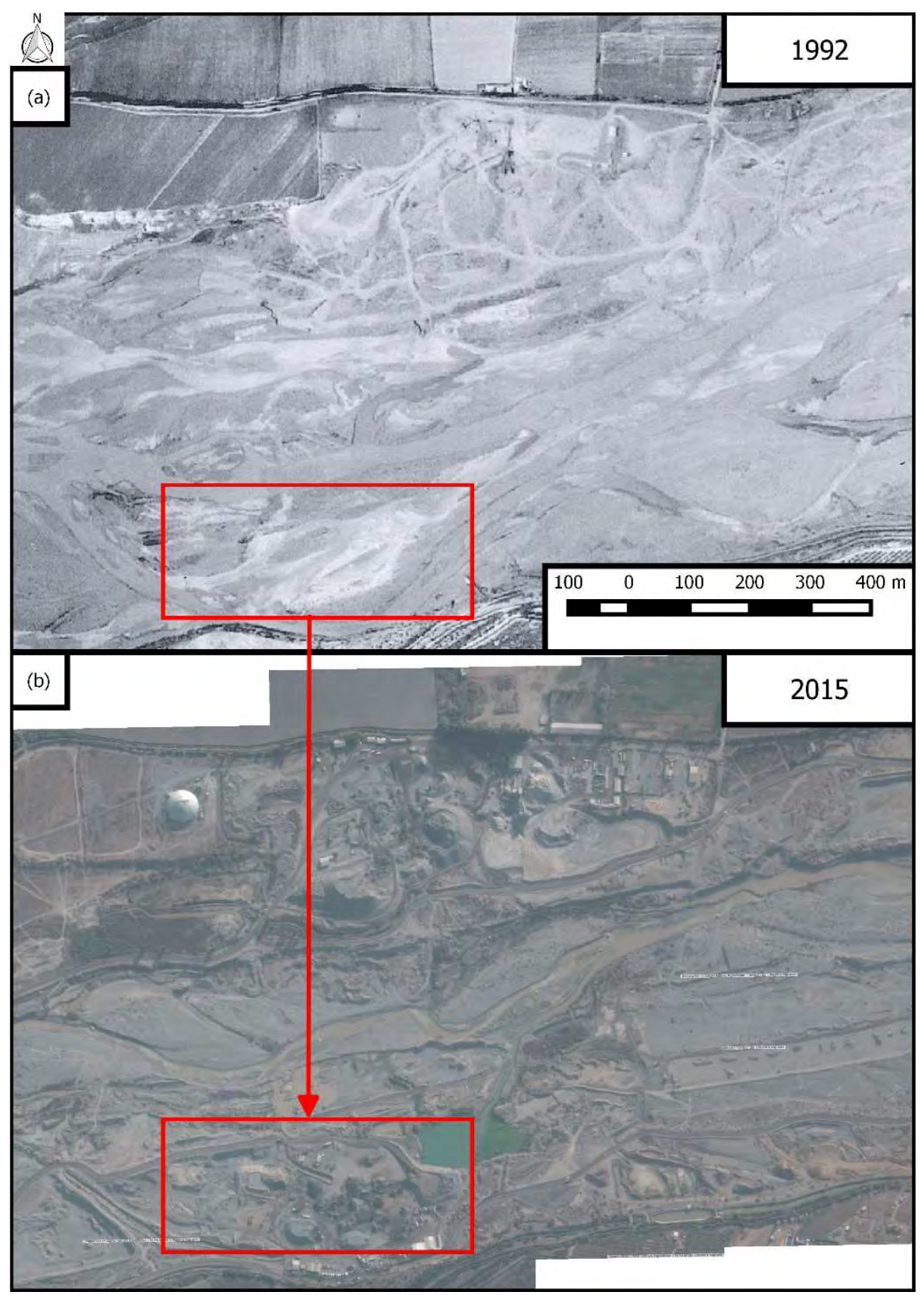

Figure 3: Introduction of human activity in the channel. Precise straight shapes can be identified from above. (a) the river flows naturally over the south bank (highlighted), however, 23 years later as observed in (b), where human intervention takes place and the main channel switches to the north bank. 


\begin{tabular}{c|c|c|c} 
Year & Source & Resolution & Max. extent (station) \\
\hline 1980 & Topography map & $2.5 \mathrm{~m}$ contours & $22,000 \mathrm{~m}$ \\
2007 & Topography & $0.5 \mathrm{~m}$ contours & $22,000 \mathrm{~m}$ \\
2009 & Topography & $2.0 \mathrm{~m}$ contours & $18,200 \mathrm{~m}$ \\
2011 & Topography & $10.0 \mathrm{~m}$ contours & $18,000 \mathrm{~m}$
\end{tabular}

The 1980 topography map included $2.5 \mathrm{~m}$ interval contours which allowed us to create the 3D surface of the terrain, and the 2007 topography data contained $0.5 \mathrm{~m}$ interval contours. Surface data from 1980 to 2011, and 2015 GlobalMapper data were transformed to DEMs and used to calculate the difference of DEMs 


\section{Results}

\subsection{Morphology features: Planform changes}

The active channel in sub-reach 1 highly depends on the operation of the water intakes and irrigation channels present in the area, and also on the three

outfalls or return pipes located on the north bank, which serve as drainage structures of the surrounding area (i.e. irrigation channels) if there is surplus water. The surplus water is delivered to the river and conveyed through the north portion of the floodplain. These water threads can be seen from 1954 to 2008, however, the active channel has suffered a migration process to the south bank. In 1954, sub-reach 1 shows a clear braided morphology until 2008. In 2015 the north portion of the main channel remained dry as the drainage structures did not return water to the river. Between years 1992 and 2008, an artificial channel was excavated to divert water from Clarillo intake, (feature C.2 in Fig. 1c), directly to the south bank.

In sub-reach 2 the channel maintains its relative position throughout the years, close to the north bank of the river. In this case, however, the river suffers a transition from braided to single thread, similar to the case of subreach 1, with the exception that no artificial channels are excavated in this section, and no water intake structures are present. From 1954 to 1992 channels are displaced to the south bank, but from 2008 onward the threads disappear and only the main channel remains to exhibit some isolated braids. In Fig. 4 we show a sample of the changes in the active channel evolution from 1954 to 2015 , for sub-reach 2.

Sub-reach 3 exhibits a very intense braided pattern in 1954, which decreases significantly in the images of 1980 , but remains almost constant up to 1992 . A new and stronger decrease takes place for years 2008 and 2015. The narrowing occurs along the entire reach with the central portion being the most affected.

To characterize the curvatures of the channels, the sinuosity was calculated for the whole study reach, and it was also segmented for each of the sub-reaches separately. Fig. 5, plots the historical evolution of the river sinuosity, showing 
an alternating behavior in sub-reaches 1 and 3. Sub-reach 2 shows a negative trend around value 1.2. The absolute maximum value of sinuosity is 1.23 in 1954 and the minimum absolute value is 1.05 for the same year. Except for year 2015, the maximum overall sinuosity is observed in sub-reach 2 .

River braiding was also measured for the entire reach of the Maipo River, and for each sub-reach in which the river reach was divided. The analysis shows that all sub-reaches exhibit a negative trend, as depicted in Fig. 5.

The highest BI was given at 1954, with an average of 3.83 for the entire study reach. The BI drops to 2.45 on 1980, then it has a slight decay to 2.28 in 1992. For 2008 there is another significant decrease of the BI to 1.71, and finally in the year 2015 the BI decreases to 1.27. The magnitude of the BI for each sub-reach of the area of study, also shows a decreasing trend as the BI in sub-reach 1 drops from 3.22 to 1 (single channel) from 1954 to 2015, subreach 2 drops from 3.24 to 1.11, and sub-reach 3 drops from 5.02 to 1.69. This analysis 325 also shows that sub-reach 3 appears as the more braided of the three sections, except for 1992 where sub-reach 2 has a slightly superior margin of $3 \%$. 


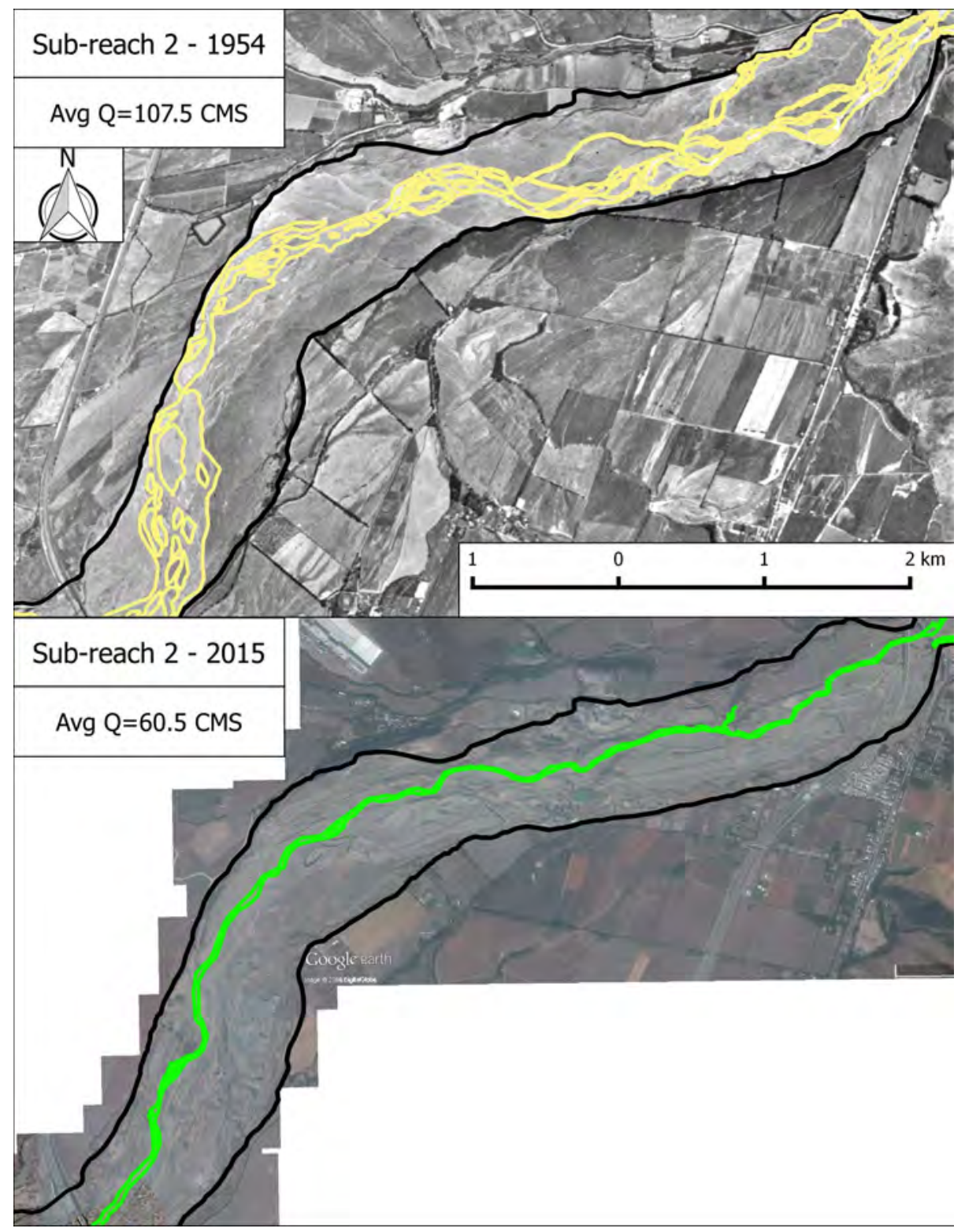

Figure 4: Identification of the active channel of the Maipo River in Sub-reach 2, from 1954 to 2015. In the lower picture, it can be seen how gravel mining activities have occupied the south bank of the river in its entire length. 


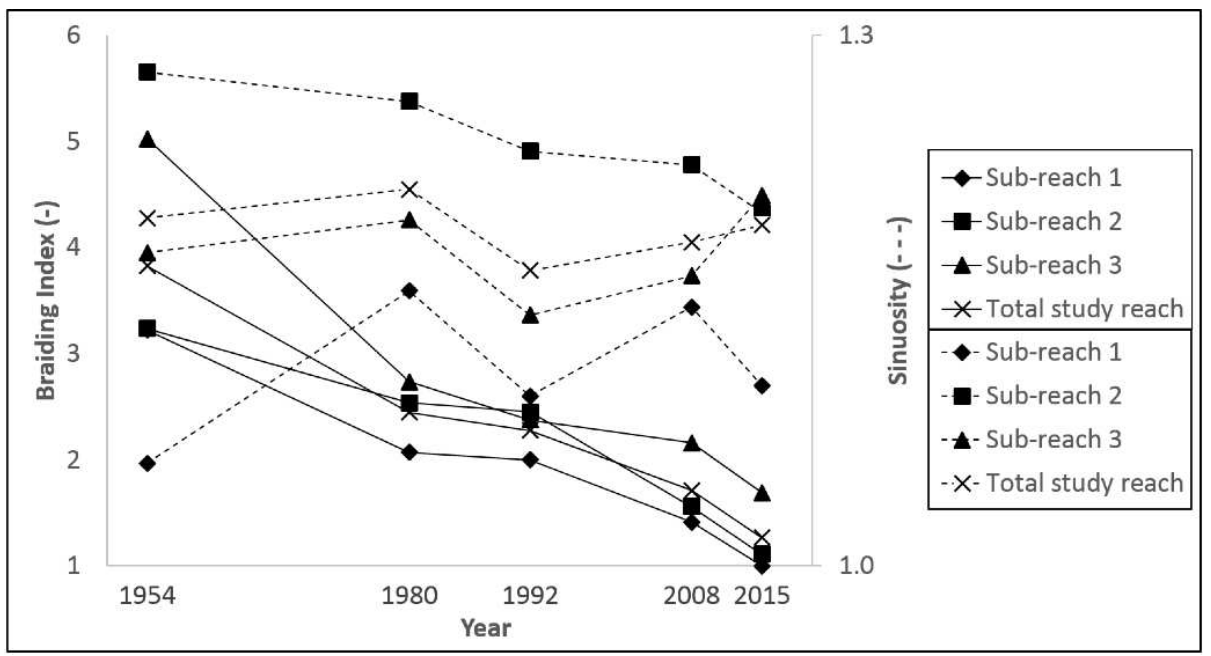

Figure 5: Changes of river braiding index (left-continuous line) and river sinuosity (rightdashed line) from 1954 to 2015. 
Three main land cover groups were identified to quantify the net change of the river bed extension in this investigation: (1) vegetation, (2) sediment bars and islands and (3) intervened sites (mostly excavation). Vegetation is clearly distinguishable specially when analyzing colored photographs. Bars are mostly given as point bars due to braiding and meanders. Islands can be seen mostly in low-flow zones. Finally intervened sites can be clearly identified because of the sharp edges performed by machinery as described in section 3.1.1. Even though large gravel mining sites are relatively easy to identify, smaller sites, pits and cuts that are present along the entire study reach, are difficult to distinguish from roads, and land movements performed through time for different reasons (such as construction roads, access roads, service roads, etc), which is why we label these areas as "intervened" and not strictly as "gravel mining".

From the available data, we obtained the land-cover evolution of the channel from 1992 to 2015. The quality and resolution of the images from 1954 and 1980 are not suitable to extract the area occupation in the reach with the same level of detail. Table 3 summarizes the land cover evolution from 1992 to 2015, depicting an increasing intervention that has transformed the land use on the floodplain for more than 20 years, for each of the subdivisions of the reach. In the same period of time, average flow decreased approximately by $25 \% \sim 30 \%$.

In Fig. 7 we show the aggregate amount of the surface area over the entire study reach.

Sub-reach 1 exhibits an increase from 2.41 to 12.61 hectares on intervened area of the channel, which corresponds to a rise of $423 \%$ during the observation period. Most of the in-stream gravel mining activities are small operations with no processing plants nor stocking plants nearby. Vegetation cover remains almost constant between 4.5 and 5.0 hectares and sediment bar land cover drops from 47.74 to 22.19 hectares (Fig. 7a).

In sub-reach 2, there was a significant increase on the gravel mining activities, 355 from 29.16 hectares in 1992, to 211.75 hectares in 2015. Processing and storage plants are present on the north and south banks of the river, and large gravel extraction sites can be clearly identified (Fig. 6b). From 1992 to 2015 the 
increase on gravel mining surface area is equal to $626 \%$, being the sub-reach with the higher percentage increase for this subject. Vegetation cover remains relatively constant, while river bars surface coverage oscillates averaging a flat trend.

Sub-reach 3 also experiences a significant increase on gravel mining surface area in the last decade. After staying almost constant from 1992 to 2008, the last period shows an approximate $261 \%$ increase While vegetation cover remains almost constant and exhibit a relative $100 \%$ increase on the last period, the sediment bar area cover rises between years 1992-2008, but then drops significantly between 2008-2015. It is also possible to realize that the gravel mining activities have been increasing in the downstream direction. Therefore, the analysis of the total land cover evolution (Fig. 7) shows that gravel mining activities have increased dramatically from 86.62 to 368.13 hectares in the entire study reach, for a total increase of $325 \%$. The surface area of bars has decreased from 115.68 to 70.90 hectares, which corresponds to a $38 \%$ decrease, and the vegetation cover has increased from 17.92 to 33.07 hectares, equal to a $85 \%$ increase.

Table 3: Summary of study reach land cover evolution. It is important to note that percentages cannot be added, since some areas overlap.

\begin{tabular}{c|c|c|c} 
& \multicolumn{3}{|c}{ Area (hectares) (\% of study reach) } \\
Year & Bars & Vegetation & Intervened (Gravel mining \& land movement) \\
\hline 1992 & $115.68(6.2 \%)$ & $17.92(1.0 \%)$ & $86.62(4.6 \%)$ \\
2008 & $119.07(6.3 \%)$ & $20.32(1.1 \%)$ & $183.73(9.8 \%)$ \\
2015 & $70.90(3.8 \%)$ & $33.07(1.8 \%)$ & $368.13(19.6 \%)$
\end{tabular}




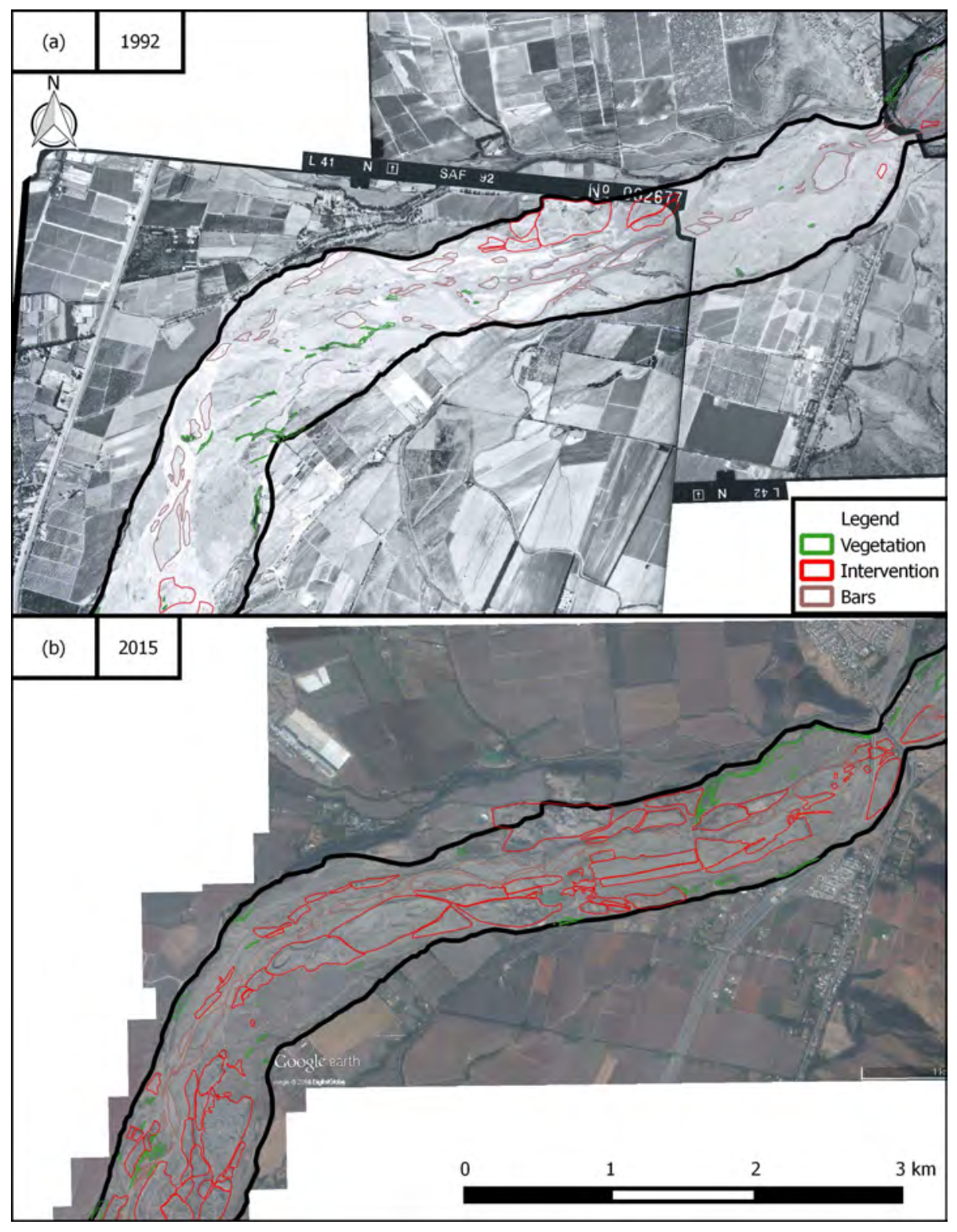

Figure 6: Land cover evolution for subreach 2 in the period 1992-2015 shows the increase of gravel mining surface area. 


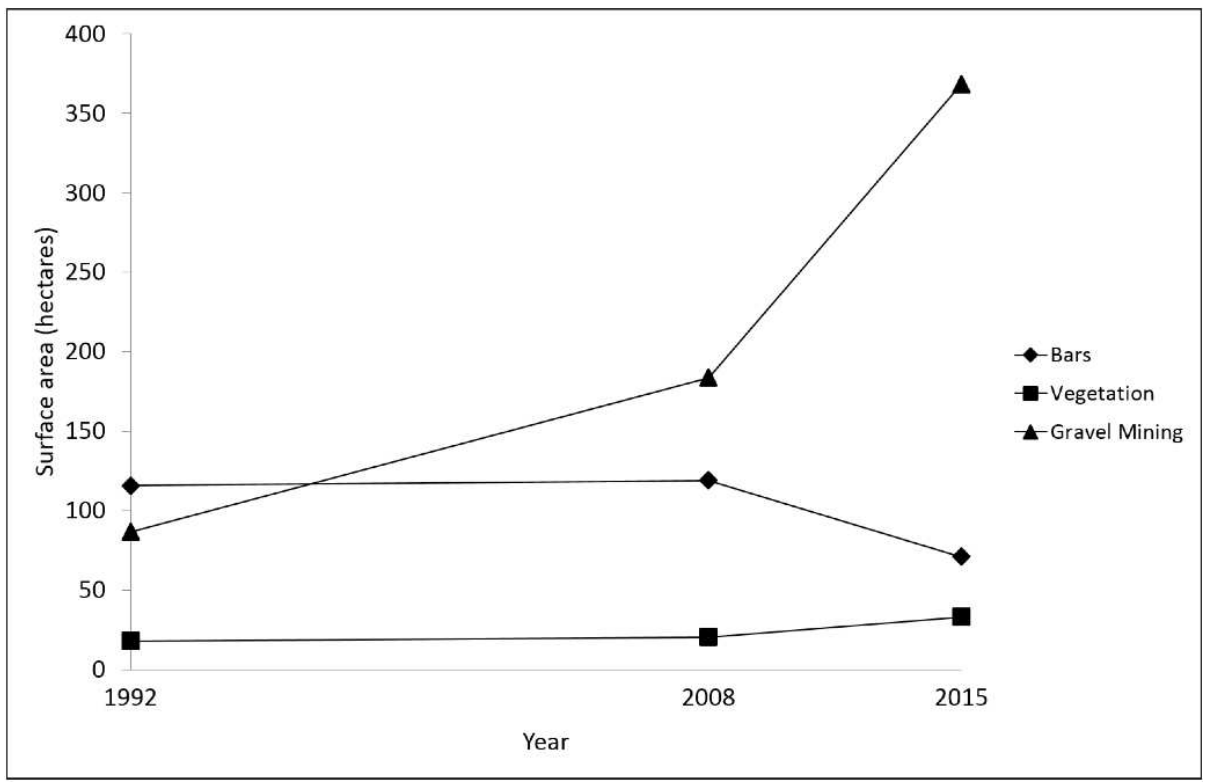

Figure 7: Quantitative chart of land-cover evolution for the entire study reach. Intervened (Gravel mining + land movement) area increases significantly over sub-reaches 2 and 3, being gravel mining the most notably impact. Sub-reach 2 shows the larger degree of intervention (Fig. 6). Vegetation coverage remains almost constant, while bar coverage depict a slight decrease. 


\subsection{Morphology features: Channel width and Elevation changes}

The topography data of the Maipo River is used to compute the bankfull width and the thalweg elevation of the river channel, with the purpose of establishing the effects of the in-stream gravel mining in the Maipo River. The channel bankfull width was measured between 1980 to 2011 using topographic data, for the entire reach and each sub-reach separately. In this time period, the river average flow decreased approximately $50 \%$.

Sub-reach 1 shows a decrease in the bankfull width for almost every station where the cross-sections of the channel were measured. The lowest values can be observed in 2007, and also a noticeable difference between 1980 and the next three years, specially in the last kilometer (stations 1700 to $2800 \mathrm{~m}$ ) where spatially coincides with the construction of the Route 79 bridge.

Sub-reach 2 exhibits that maximum width values are given during 1980 then a strong decrease to 2007, just like sub-reach 1. For the 2007-2009 and 20092011 periods, the decreasing continued, with the year 2009 having on average the lowest values of bankfull width. A small portion of sub-reach 2 in 2015 was measured with the UAV flight. Stations 2800 to 3800 were measured, showing the lowest bankfull width value for the entire series, due to gravel mining activities in both north and south banks. Largest narrowing values were registered for stations 6400 to 6800 where 5.7 hectares of the north bank were intervened for gravel mining, as observed in Fig. 9b.

Sub-reach 3 shows the highest values for year 1980, and a sustained decrease in subsequent years. In this case, year 2011 shows in average the lowest values of bankfull width. Between stations 10200 and 12000, years 2007, 2009 and 2011 show a small narrowing trend, but past this point, narrowing becomes more evident, specifically in stations 12000 through 13000 where important gravel mining operations establish in the south bank of the river (Fig. 9c-d).

As in sub-reach 2, a small portion of sub-reach 3 is available through the UAV flight, where stations 10200 to $10600 \mathrm{~m}$ show a very low bankfull width for year 2015, due to heavy presence of gravel mining (Fig. 9e-f).

An average width is also computed for all sub-reaches, obtaining a difference 
per year rate for all periods. Between 1980 and 2007 a decrease of $18 \mathrm{~m}$ per year is observed, between 2007 and 2009 a decrease of $44 \mathrm{~m}$ per year and finally an increase of $13 \mathrm{~m}$ per year between 2009 and 2011. The overall trend is a decreasing bankfull width given by the increasing presence of human intervention areas (Table 4).

Table 4: Average bankfull width for the study reach of the Maipo River. All sub-reaches show an average negative trend (channel narrowing), being sub-reach 3 the most affected. Average river discharge in the 1980-2011 period decreased $\approx 50 \%$

\begin{tabular}{c|c|c|c|c} 
& \multicolumn{4}{|c}{ Average bankfull width (m) } \\
Year & 1980 & 2007 & 2009 & 2011 \\
\hline Sub-reach 1 & 800.9 & 646.5 & 677.4 & 669.8 \\
Sub-reach 2 & 1196.8 & 698.5 & 596.5 & 721.9 \\
Sub-reach 3 & 1296.8 & 864.2 & 627.5 & 573.0 \\
\hline Study reach avg. & 1174.8 & 772.1 & 621.7 & 652.5
\end{tabular}

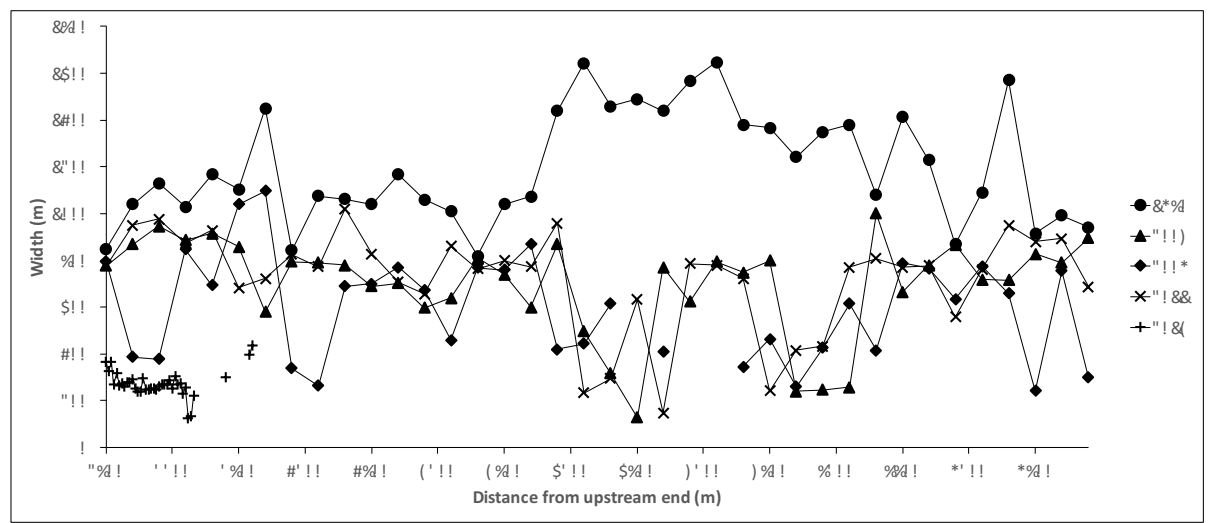

Figure 8: Bankfull width for sub-reach 2. Lowest values of channel width are measured in 2015 for the first portion of the sub-reach, which spatially corresponds with the downstream part of the Route 79 bridge site.

Regarding thalweg elevation, for sub-reach 1, year 1980 shows the highest 
values and subsequent years show a steady descent, with year 2011 being the lowest. For sub-reach 1, stations 2600 and $2800 \mathrm{~m}$ show the largest drop in elevation, which coincide with the construction of the Route 79 Bridge.

In the case of sub-reach 2, year 2011 appears as the lowest elevation profile again but with no major differences compared to year 2009. Largest differences in elevation are given at stations 4800 to 5200, which coincide with a large gravel mining sector located at the north bank (Fig. 10), where the increase of the intervened area is evident. Sub-reach 3 shows the most significant changes in the 1980-2000's period, showing two heavy excavation processes within the channel. Consistency between 2007, 2009, and 2011 rule out the possibility of an outlier value. Averaging through the entire study reach, thalweg elevation shows a negative trend across time (see Table 5). Between 1980 and 2007 the loss is $14.1 \mathrm{~cm}$ per year, between 2007 and 2009 the loss is $41.7 \mathrm{~cm}$ per year and finally between 2009 and 2011 the loss is $35.3 \mathrm{~cm}$ per year.

Table 5: Average thalweg elevation for the Maipo River study reach.

\begin{tabular}{c|c|c|c|c} 
& \multicolumn{4}{|c}{ Average thalweg elevation (m) } \\
\hline Year & 1980 & 2007 & 2009 & 2011 \\
\hline Sub-reach 1 & 585.14 & 584.37 & 584.02 & 582.21 \\
Sub-reach 2 & 538.00 & 533.70 & 532.56 & 531.64 \\
Sub-reach 3 & 464.62 & 460.29 & 459.59 & 459.20 \\
\hline Study reach avg. & 511.95 & 508.14 & 507.30 & 505.67
\end{tabular}

The Difference of DEM's results are shown in Fig. 12, where the net difference DEM raster is presented in grayscale, where lighter tones represent aggradation, and black color erosion (degradation). In both figures the aerial photograph analysis is overlayed. Most of the dark zones of the raster coincide with the intervened polygons especially in the larger sites. The net erosion volume was computed to be 39.4 millions of $\mathrm{m}^{3}$. 
Table 6: Difference of DEM's applied to the study reach. Computation for 1980-2011 period

\begin{tabular}{c|c|c|c|c} 
& Erosion & Deposition & Net & Rate ()$/$ per year \\
\hline Area $\left(\mathrm{m}^{2}\right)$ & $13,444,671$ & $8,111,173$ & $-5,333,498$ & 172,048 \\
Volume $\left(\mathrm{m}^{3}\right)$ & $58,126,216$ & $18,711,914$ & $-39,414,302$ & $1,271,429$
\end{tabular}

\subsection{Correlation analysis}

To determine if elevation changes are related to planform changes monotonically, a correlation analysis was performed between the bed elevation and the bankfull width variation using the Spearman rank correlation function, defined as follows,

$$
\rho_{S}=\frac{\operatorname{cov}\left(r_{x}, r_{y}\right)}{\sigma_{r_{x}} \sigma_{r_{y}}}
$$

where $n$ pairs of variables are assigned to rankings $\left(r_{x}\right.$ and $\left.r_{y}\right)$ and a regular Pearson correlation is computed between the ranks. In our analysis, the variables were the bed elevation change $\Delta z_{t h}$ and the bankfull width change $\Delta w_{B F}$. A total of four series of rankings were assembled, for each registered period (1980-2007, 2007-2009, 2009-2011 and 1980-2011)

The computed value of correlation is equal to $\rho_{S}=0.162$ for the total cumulative change during the period from 1980 to 2011 for the full study reach, not differentiating between intervened or non-intervened zones. This magnitude of $\rho_{S}$, does not provide a significant statistical association between the variables. However, the scatter plot of the thalweg change measurements vs the bankfull width change show most of the observations occupy the third quadrant as depicted in Fig. 13. This result implies that large channel incisions not necessarily mean a significant narrowing, but almost every incised cross section has shown narrowing during the period of study. Correlation values are presented for each period in Table 7 .

To address the importance and influence of gravel mining, a correlation analysis was performed considering only the intervened zones (i.e: cross sections where no intervention was detected were ruled out of the analysis) of 
for Spearman and Pearson correlation of 0.56 and 0.44 respectively, showing a stronger positive relationship between these phenomena when the river is intervened.

Between 1980 and 2007, most of the changes detected were narrowingincision. Also, isolated cases of aggradation were reported which could be associated to cut and fill processes in river intervention due to bridge or road construction, but there is no evidence for it, since it is difficult to distinguish if gravel extracted outside pits was effectively removed from the fluvial system or simply relocated (as it would be in a non consumptive use). Most of the narrowing-incision processes took place in sub-reach 2 , as shown in the average bankfull width time evolution, at $1197 \mathrm{~m}$ to $699 \mathrm{~m}$ average width decrease. Spearman and Pearson correlations for narrowing and incision are around 0.4 or 0.5 showing an evident relationship between them (Table 7).

Between years 2007 and 2009, all four combinations (narrowing-incision, narrowing-aggradation, widening-incision and widening-aggradation) were reported, being incision the predominant process with 51 of 75 valid measurements. Narrowing and widening processes are roughly balanced whether incision or aggradation is present, which is coherent with the low correlation values shown in table 7 for the 2007-2009 period. Most of the reported incisions are located in sub-reaches 2 and 3, corresponding to 22 and 21 cases respectively, out of 75 total. In total 24 out of 75 sections suffered minor aggradation on average, which corresponds to values smaller than $4 \mathrm{~m}$.

Between 2009 and 2011, incision again is the predominant process, with 47 of 71 valid measurements. However narrowing and widening are distributed almost equally, with 24 vs 23 measurements, explaining again the low correlation values from table 7 in that period. Most of the incision takes place in sub-reaches 2 and 3, with its mean values being the same as the 2007-2009 period. Average aggradation however decreases in sub-reaches 2 and 3 . 
Table 7: Correlation table for planform vs vertical changes, full study reach

\begin{tabular}{c|cccc} 
& \multicolumn{5}{|c}{ Period } \\
& $1980-2007$ & $2007-2009$ & $2009-2011$ & $1980-2011$ (total) \\
\hline Spearman $\rho$ & 0.443 & -0.015 & -0.095 & 0.162 \\
Pearson $\rho$ & 0.497 & -0.087 & -0.238 & 0.114
\end{tabular}




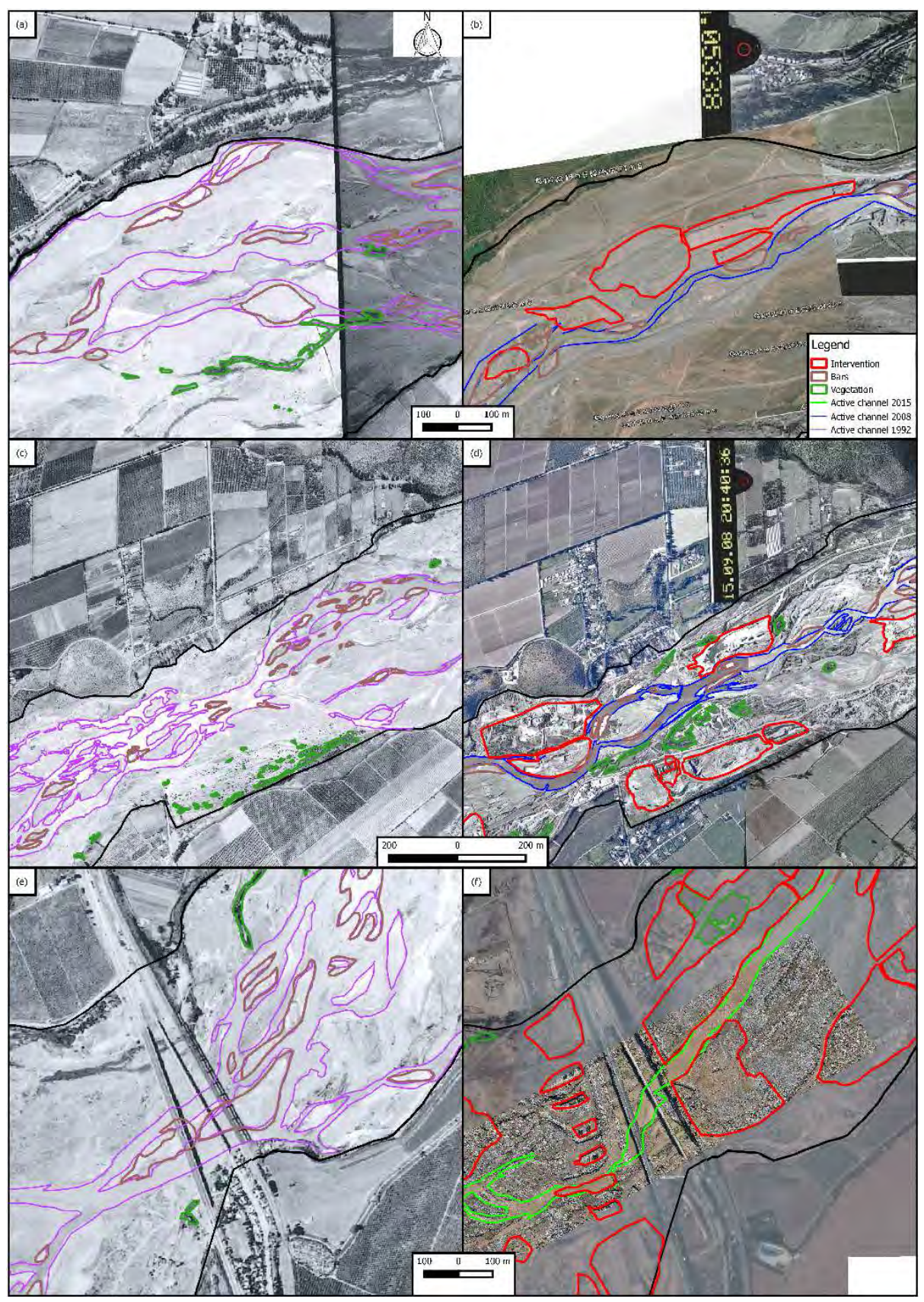

Figure 9: Maipo River in 1992 (a-c-e), 2008 (b-d) and 2015 (f). North bank occupied by gravel mining, moving the river active channel to the south (a-b). Mining sites of significant size appear in both north and south banks of Maipo River (c-d). Heavy intervention present due to bridge maitenance and new construction (e-f) 


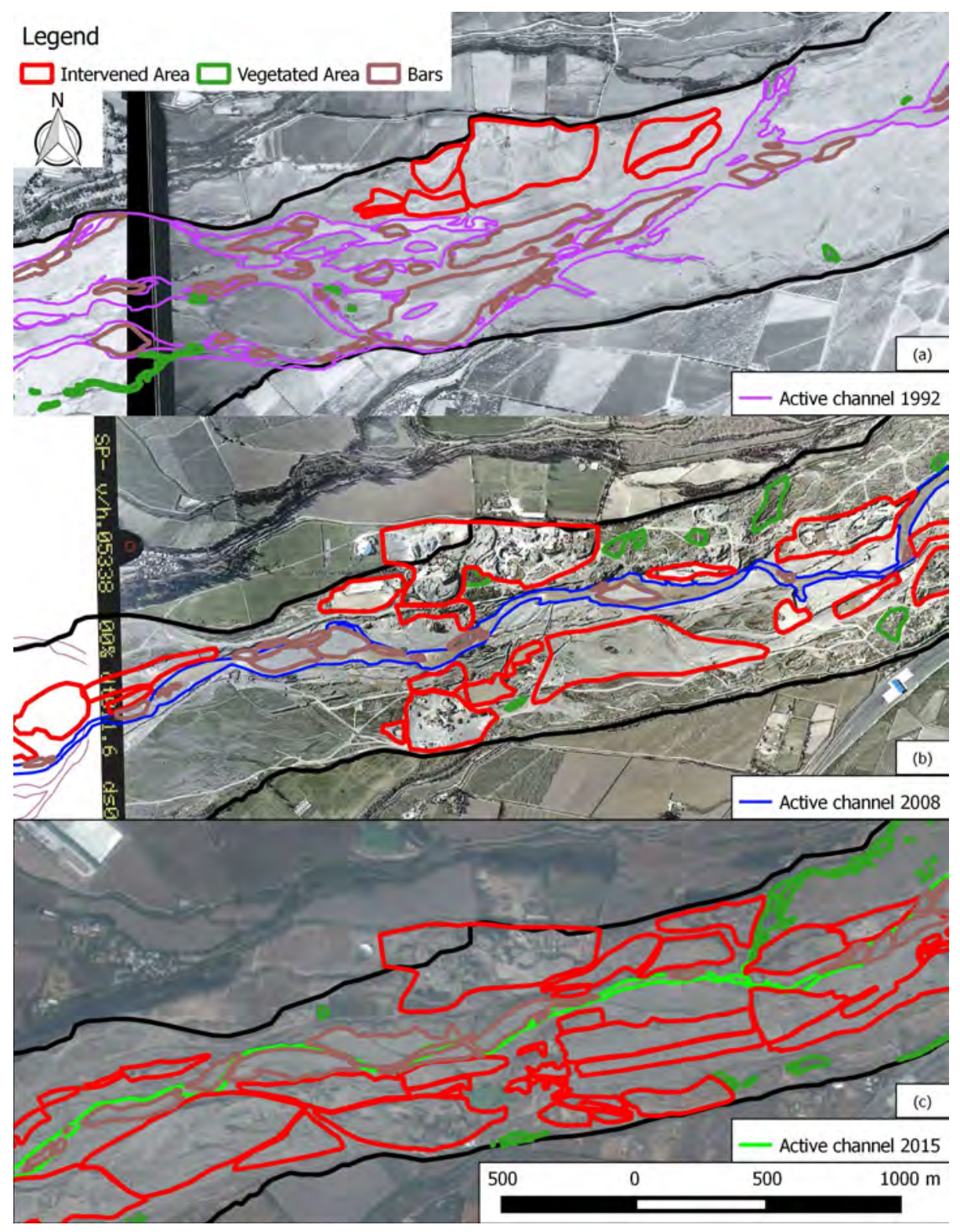

Figure 10: Full evolution of a selected section of sub-reach 2 (upstream of Route 5 bridges) from 1992 (a), to 2008 (b) and 2015 (c). Intervened areas occupy the floodplain towards the south bank. 


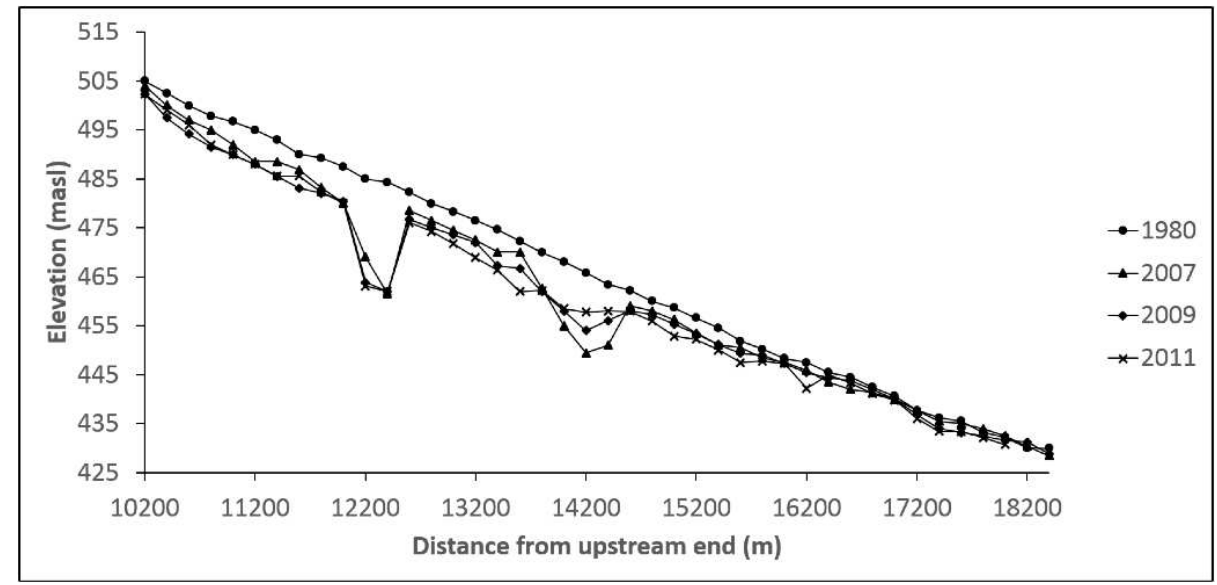

(a)

Figure 11: Cross section minimum elevation from 1980 to 2011 for sub-reach 3, where a large difference can be noticed at stations $12200 \mathrm{~m}$ and 14200. These features are explained by deep gravel extraction pits installed in the river main channel after 1980. At station 16200, a new extraction pit is starting to develop, since it shares the same type of geometry as stations 12200 and $14200 \mathrm{~m}$. 


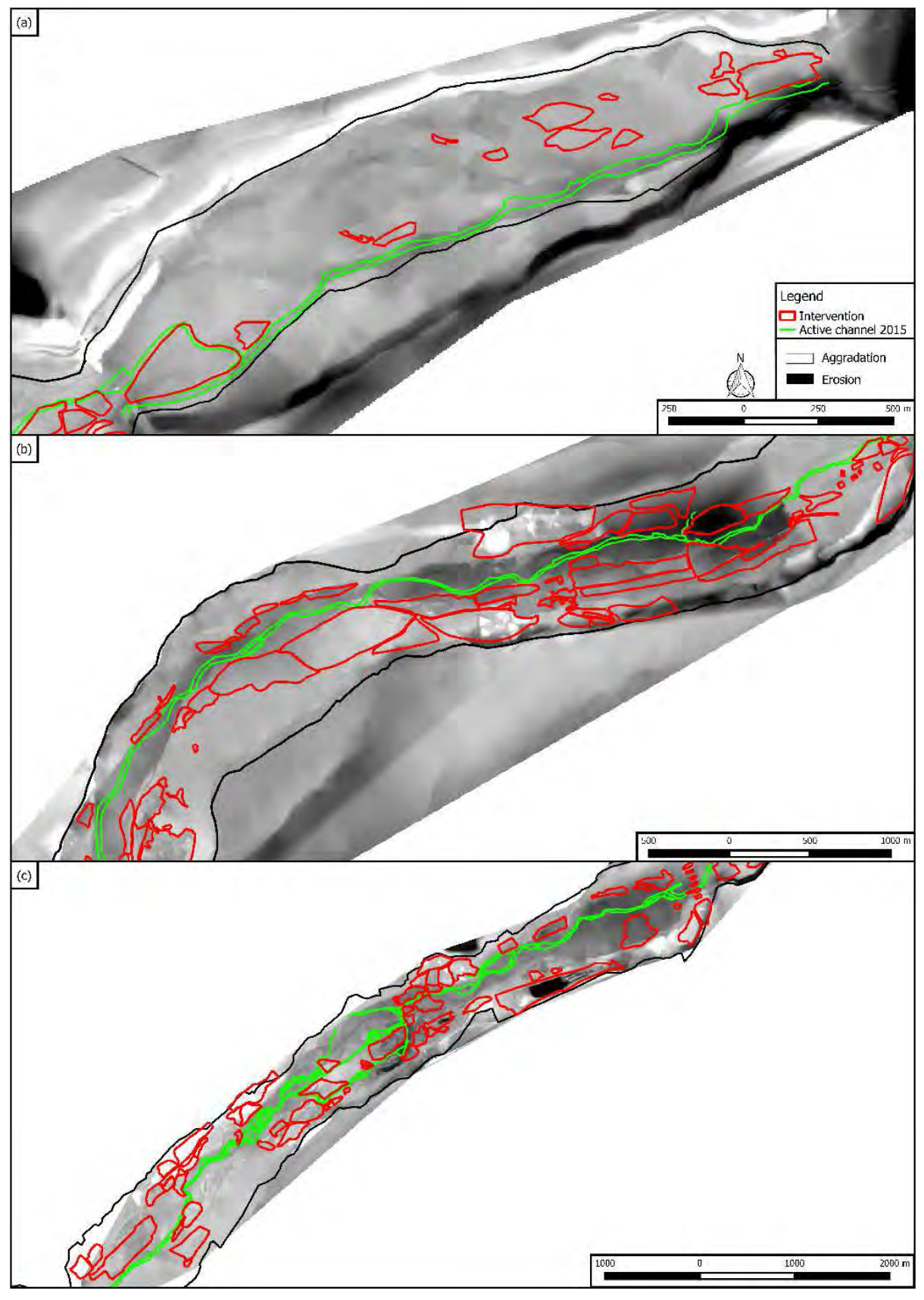

Figure 12: (a-c): DEM difference raster for sub-reaches 1, 2 and 3 respectively. 


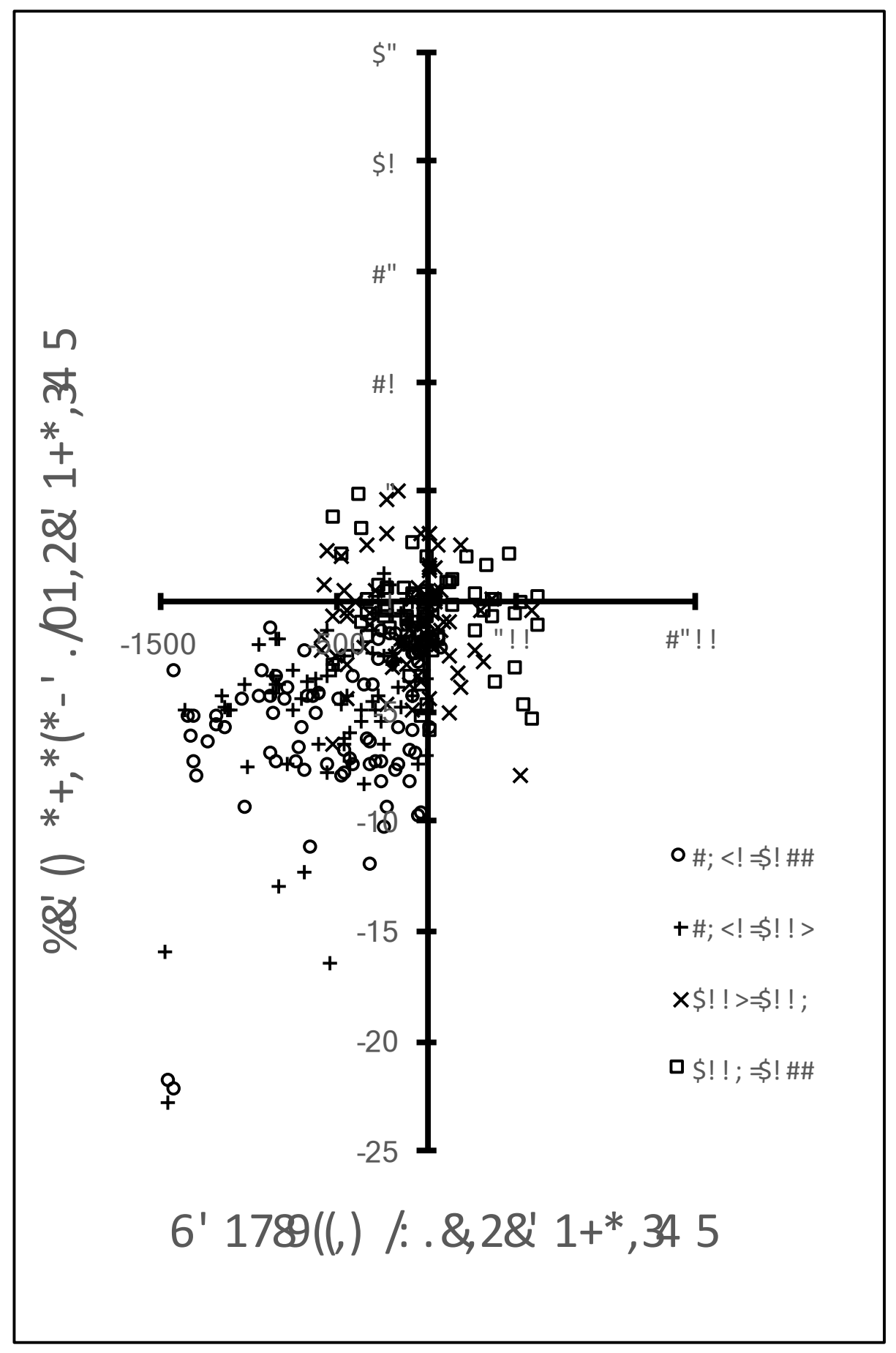

Figure 13: Bankfull width vs thalweg elevation 


\section{Discussion}

\subsection{Relation between vertical and planimetric changes}

The observed trend of narrowing-incision in the early years of this study is similar to the main trend of Italian, Spanish and Polish rivers that went under gravel mining (e.g. Surian and Rinaldi, 2003, 2004; Rivas et al., 2006; Surian et al., 2009; Martín-Vide et al., 2010; Scorpio and Rosskopf, 2016; Wyżga, 2007;

${ }_{485}$ Wyżga et al., 2016), where river channels underwent a long phase of narrowing (80\%) and 8-10 $\mathrm{m}$ of incision in the case of Italian rivers and 4-5 $\mathrm{m}$ of incision at Spanish and Polish rivers. The narrowing-incision processes are the most intense at the initial phase, if we refer to the average width and elevation loss rate computed for our study $(-18 \mathrm{~m} /$ year for width and -17 to $-40 \mathrm{~cm} /$ year for elevation).

At the middle stages, correlation analysis yielded very low association between narrowing and incision, somehow similar to the findings of Comiti et al. (2011), where aggradation/degradation shows little to no correlation with narrowing/widening.

This behavior is also observed in Surian et al. (2009) and Comiti et al. (2011), where incision remains as the primary process while narrowing slows down or even may revert to widening (low correlation overall), as is the case for the 2009-2011 period (Table 7), however a major difference is present: in Italian rivers, gravel mining was banned, in contrast to the Maipo River, where gravel mining is currently at a blooming stage. The matter becomes more intriguing as the Maipo River average flow is decreasing over time, leaving even less sediment recharge possibilities.

\subsection{River vegetation and morphological changes due to human intervention}

From the analysis of the images, it is possible to determine the location and evolution of sediment bars in the sub-reaches for the entire period, as well as the vegetation covering in the vicinity of the channel. In sub-reach 1 , sedimentation bars have been clearly affected by gravel mining, as bar presence dropped down 
as gravel mining operations increased. The correlation analysis yields a Pearson coefficient of $\rho_{P}=-0.98$. As the channel conveyed the flow towards the south bank, sedimentation bars present in the rest of the riverbed were exploited, extracting all the gravel that had been deposited in bars. Vegetation however did not present any considerable variations, except for some encroachment that can be noted in the last third of the reach. Sub-reach 2 shows almost no correlation between sediment bars area and gravel mining area, with a Pearson correlation 515 of $\rho_{P}=-0.09$, suggesting that in this reach new extraction sites have been established in the floodplain which is confirmed by Fig. 6, where new sites appear close to the upstream and downstream boundaries. Results exposed in Table 4 support this fact as a significant general narrowing takes place between 1980 and 2009 (40\% width loss in the period) . Since this sub-reach is almost dry most of the time, as the entire discharge is distributed in irrigation channels, the vegetation presence is mostly confined to the river banks due to the presence of these channels. Sub-reach 3 shows a different scenario, where vegetation presence and bars have negative correlation through time $\left(\rho_{P}=-0.65\right)$. The same happens for bars and intervened areas with a $\rho_{P}=-0.71$, while vegetation slightly increases with time showing positive correlation with intervened areas $\left(\rho_{P}=0.98\right)$.

Particularly, by analyzing only the cross sections that coincide with areas identified by air photographs, the vast majority of the intervened area presents negative change of elevation and width where the largest changes are given at sub-reaches 2 and 3, where vast extraction zones have established (Fig. 10). In these particular sites, compared to 1980, $20 \mathrm{~m}$ of depth have been lost in the floodplain, and over 21 hectares of river were intervened.

As discussed previously, incision and narrowing are present mainly in subreaches 2 and 3, which coincides with the accelerated expansion rate of gravel 535 mining sites (see Fig. 6). Gravel mining operations have grown in the Maipo River at a significant rate and therefore river morphology has been affected by showing mostly narrowing and incision. In-stream mining would cause large values of thalweg elevation changes $(\Delta z)$ and bankfull width values to have 
small variations, while river bank or floodplain extraction would cause small variations on the thalweg elevation, but increased bankfull width, producing a widening of the channel. This is supported by the photographic evidence exposed in this investigation.

Vegetation presence has remained almost constant, with small fluctuations between periods of time. In contrast to what has been observed in other experiencies (e.g. Kondolf (1997); Zanoni et al. (2008); Comiti et al. (2011)) where vegetation encroachment has manifested, in the Maipo River the climate is semi-arid, while the mentioned studies are mostly performed at mediterranean climates such as Europe.

\subsection{Study limitations}

As mentioned in section 2, official stream gauges are absent at the study reach, which makes more difficult our interpretation of results due to the uncertainty of the available (and sometimes incomplete) data. Incision effects are often associated and interpreted alongside stream data. Another limitation is the inability to distinguish between extracted volume and relocated volume, 555 since no official records of gravel mining have been given by the stakeholders. Air photographs provide a good reference of mining sites, however it is difficult to determine if $100 \%$ of the extracted volume on that site has been moved out of the river or relocated to an in-stream processing plant/pit. Our closest approach to a more accurate value is the $\mathrm{DoD}$, which is subject to propagation of error. ${ }_{560}$ The DoD analysis yielded a total net volume of -39.41 millions of $\mathrm{m}^{3}$ (Table 6 ). This value is a net one calculated upon strict difference between the terrain data available. In this calculation, natural and artificial erosion-aggradation processes are involved, without the possibility of filtering gravel mining from construction intervention for example. Even though this restriction, it is possible to contemplate the significant impacts that have affected the river, and that a great part are due to gravel mining as shown in this research. This rate of lost volume is significantly larger than those reported by Comiti et al. (2011) (6 millions of $\mathrm{m}^{3}$ ), and comparable with the rates exhibited by the Po basin 
(Surian and Rinaldi, 2003) with $\approx 3$ million $\mathrm{m}^{3}$ per year, and 12 million $\mathrm{m}^{3}$ per year at its highest rate, while the Maipo shows approximately 1.3 million $\mathrm{m}^{3}$ per year (Table 6).

\section{Conclusions}

In this investigation we performed the first quantitative analysis of the morphodynamic evolution in a section of the Maipo River affected by gravel mining, located in the Metropolitan Region of Santiago, Chile.

The influence of human intervention on the Maipo river is assessed, by focusing on measuring the effects of gravel mining with the use of aerial photographs, satellite images and topographic data surveyed for the past 60 years. The planform and elevation analysis yielded three important results: (1) sustained intervention (gravel mining and land movements) on the Maipo River have significantly reduced the braiding pattern of the river and forcing a lateral channel migration to non-extraction zones, (2) the Maipo River has experienced mostly narrowing and degradation due to the spreading and intensification of gravel mining activities, finding similar results as other researchers have found in Italian, Spanish and Polish rivers, however with different flow and climate conditions. Measurements yield an average of $35 \mathrm{~cm} /$ year of degradation, 15 $\mathrm{m} /$ year of narrowing of the floodplain and 39 million $\mathrm{m}^{3}$ of net volume loss; finally (3) gravel mining sites alone have increased their surface coverage in 325\% between 2015 and 1992 (the first year available of measurements) and have expanded downstream, affecting the existing infrastructures. The most affected section of the study reach is the vicinity the bridges, where the largest sites are located, posing a great vulnerability, if the current width and elevation losses are persistent in time.

In economical terms, the Maipo River is the most important in Chile, which underscores the necessity of creating awareness about the need for an effective management, both in the short and the long term; not just the water resources provided by the river, but also as a key element of the transportation infras- 
tructure. With multiple users and stakeholders converging on the Maipo basin, a lack of integrated management, and a sustained economic growth, the Maipo River poses an interesting case of study, due to the fact that it is going through active development, allowing scientists and authorities to assess in real time the restoration and management strategies designed upon the lessons learned from past experiences.

\section{Acknowledgements}

This work has been supported by Fondecyt project 1130940 and Conicyt/Fondap grant 15110017. We thank Mr. Javier Carvallo for providing the bathymetric information of the Maipo River employed in the analyses. 


\section{References}

Andreoli, A., Mao, L., Iroume, A., Arumi, J. L., Nardini, A., Pizarro, R., Caamano, D., Meier, C., Link, O., 2012. The need for a hydromorphological approach to chilean river management. Revista Chilena de Historia Natural $85(3)$.

Arnaud, F., Piégay, H., Schmitt, L., Rollet, A., Ferrier, V., Béal, D., 2015. Historical geomorphic analysis (1932-2011) of a by-passed river reach in process-based restoration perspectives: The old rhine downstream of the kembs diversion dam (france, germany). Geomorphology 236 (Supplement C), $163-177$.

URL http://www.sciencedirect.com/science/article/pii/ S0169555X15000926

Batalla, R. J., 2003. Sediment deficit in rivers caused by dams and instream gravel mining. are view with examples from ne spain. Cuaternario y Geomorfología, 2003, núm. 17, p. 79-91.

Belletti, B., Nardi, L., Rinaldi, M., Jan 2016. Diagnosing problems induced by past gravel mining and other disturbances in southern european rivers: the magra river, italy. Aquatic Sciences 78 (1), 107-119.

URL https://doi.org/10.1007/s00027-015-0440-5

Bollati, I., Pellegrini, L., Rinaldi, M., Duci, G., Pelfini, M., 2014. Reach-scale morphological adjustments and stages of channel evolution: The case of the trebbia river (northern italy). Geomorphology 221 (Supplement C), 176 186.

URL http://www.sciencedirect.com/science/article/pii/ S0169555X14003055

Comiti, F., Canal, M. D., Surian, N., Mao, L., Picco, L., Lenzi, M., 2011. Channel adjustments and vegetation cover dynamics in a large gravel bed river over the last 200 years. Geomorphology 125 (1), 147 - 159. 
URL

http://www.sciencedirect.com/science/article/pii/

S0169555X10004046

Cortés, G., Vargas, X., McPhee, J., 2011. Climatic sensitivity of streamflow timing in the extratropical western andes cordillera. Journal of Hydrology 405 (1), $93-109$.

URL

http://www.sciencedirect.com/science/article/pii/ S0022169411003234

Downward, S., Gurnell, A., Brookes, A., 1994. A methodology for quantifying river channel planform change using gis. IAHS Publications-Series of Proceedings and Reports-Intern Assoc Hydrological Sciences 224, 449-456.

Friend, P., Sinha, R., 1993. Braiding and meandering parameters. Geological Society, London, Special Publications 75 (1), 105-111.

Gaillot, S., Piégay, H., 1999. Impact of gravel-mining on stream channel and coastal sediment supply: example of the calvi bay in corsica (france). Journal of Coastal Research, 774-788.

Garreaud, R., 2013. Warm winter storms in central chile. Journal of Hydrometeorology 14 (5), 1515-1534.

Geographics, B. M., 2009. Global Mapper Geographic Information System. Blue Marble Geographics.

Gob, F., Houbrechts, G., Hiver, J., Petit, F., 2005. River dredging, channel dynamics and bedload transport in an incised meandering river (the river semois, belgium). River Research and Applications 21 (7), 791-804.

Godoy, C., Gatica, C., Niño, Y., McPhee, J., 2010. Towards management and regulation of gravel mining in urban areas of santiago, chile: Analysis of the sediment budget in maipo river. River Flow, $1443-1450$.

Gurnell, A., Downward, S., Jones, R., 1994. Channel planform change on the river dee meanders, 1876-1992. River Research and Applications 9 (4), 187204. 
Hughes, M. L., McDowell, P. F., Marcus, W. A., 2006. Accuracy assessment of georectified aerial photographs: Implications for measuring lateral channel movement in a gis. Geomorphology 74 (1), $1-16$.

URL http://www.sciencedirect.com/science/article/pii/ S0169555X05001972

James, L. A., Hodgson, M. E., Ghoshal, S., Latiolais, M. M., 2012. Geomorphic change detection using historic maps and dem differencing: The temporal dimension of geospatial analysis. Geomorphology 137 (1), 181 - 198, geospatial Technologies and Geomorphological Mapping Proceedings of the 41st Annual Binghamton Geomorphology Symposium.

URL http://www.sciencedirect.com/science/article/pii/ S0169555X11002923

Kondolf, G. M., 1994a. Environmental planning in regulation and management of instream gravel mining in california. Landscape and Urban Planning $29(2), 185-199$.

URL

http://www.sciencedirect.com/science/article/pii/ 0169204694900272

Kondolf, G. M., 1994b. Geomorphic and environmental effects of instream gravel mining. Landscape and Urban Planning 28 (2), 225 - 243.

URL http://www.sciencedirect.com/science/article/pii/ 0169204694900108

Kondolf, G. M., 1997. Profile: hungry water: effects of dams and gravel mining on river channels. Environmental management 21 (4), 533-551.

Kondolf, G. M., Piégay, H., Landon, N., Mar 2007. Changes in the riparian zone of the lower eygues river, france, since 1830. Landscape Ecology 22 (3), $367-384$.

URL https://doi.org/10.1007/s10980-006-9033-y

Lane, S. N., Westaway, R. M., Murray Hicks, D., 2003. Estimation of erosion and deposition volumes in a large, gravel-bed, braided river using synoptic 
remote sensing. Earth Surface Processes and Landforms 28 (3), 249-271.

URL http://dx.doi.org/10.1002/esp.483

Leopold, L. B., Wolman, M. G., 1957. River channel patterns: braided, meandering, and straight. US Government Printing Office.

Little, P. J., Richardson, J. S., Alila, Y., 2013. Channel and landscape dynamics in the alluvial forest mosaic of the carmanah river valley, british columbia, canada. Geomorphology 202 (Supplement C), 86 - 100, process geomorphology and ecosystems: Disturbance regimes and interactions.

URL http://www.sciencedirect.com/science/article/pii/ S0169555X13002006

Martín-Vide, J., Ferrer-Boix, C., Ollero, A., 2010. Incision due to gravel mining: Modeling a case study from the gállego river, spain. Geomorphology 117 (3), 261 - 271, introduction to Management of Large Rivers.

URL

http://www.sciencedirect.com/science/article/pii/ S0169555X09002438

Mertes, L. A., 2002. Remote sensing of riverine landscapes. Freshwater biology 47 (4), 799-816.

Milan, D. J., Heritage, G. L., Large, A. R., Fuller, I. C., 2011. Filtering spatial error from dems: Implications for morphological change estimation. Geomorphology 125 (1), 160 - 171.

URL http://www.sciencedirect.com/science/article/pii/ S0169555X10004058

Petit, F., Poinsart, D., Bravard, J.-P., 1996. Channel incision, gravel mining and bedload transport in the rhône river upstream of lyon, france ("canal de miribel"). CATENA 26 (3), $209-226$.

URL http://www.sciencedirect.com/science/article/pii/ $034181629500047 \mathrm{X}$ 
Rinaldi, M., Wyżga, B., Surian, N., 2005. Sediment mining in alluvial channels: physical effects and management perspectives. River Research and Applications 21 (7), 805-828.

URL http://dx.doi.org/10.1002/rra.884

Rivas, V., Cendrero, A., Hurtado, M., Cabral, M., Giménez, J., Forte, L., del Río, L., Cantú, M., Becker, A., 2006. Geomorphic consequences of urban development and mining activities; an analysis of study areas in spain and argentina. Geomorphology 73 (3), 185 - 206.

URL http://www.sciencedirect.com/science/article/pii/ S0169555X0500259X

Scorpio, V., Aucelli, P. P., Giano, S. I., Pisano, L., Robustelli, G., Rosskopf, C. M., Schiattarella, M., 2015. River channel adjustments in southern italy over the past 150years and implications for channel recovery. Geomorphology 251 (Supplement C), 77 -90, emerging geomorphic approaches to guide river management practices.

URL http://www.sciencedirect.com/science/article/pii/ S0169555X15300738

Scorpio, V., Rosskopf, C. M., 2016. Channel adjustments in a mediterranean river over the last 150 years in the context of anthropic and natural controls. Geomorphology 275 (Supplement C), 90 - 104.

URL http://www.sciencedirect.com/science/article/pii/ S0169555X16301258

Sernageomin, 2016. Registro de principales desastres en chile desde 1980. Tech. rep., Sernageomin, Gobierno de Chile.

Surian, N., Rinaldi, M., 2003. Morphological response to river engineering and management in alluvial channels in italy. Geomorphology 50 (4), $307-326$.

URL

http://www.sciencedirect.com/science/article/pii/ S0169555X02002192 
Surian, N., Rinaldi, M., 2004. Channel adjustments in response to human alteration of sediment fluxes: examples from italian rivers. IAHS publication 288, $276-282$.

Surian, N., Rinaldi, M., Pellegrini, L., Audisio, C., Maraga, F., Teruggi, L., Turitto, O., Ziliani, L., 2009. Channel adjustments in northern and central italy over the last 200 years. Geological Society of America Special Papers $451,83-95$.

Warner, R. F., 2012. Environmental impacts of hydroelectric power and other anthropogenic developments on the hydromorphology and ecology of the durance channel and the etang de berre, southeast france. Journal of Environmental Management 104 (Supplement C), 35 - 50.

URL

http://www.sciencedirect.com/science/article/pii/ S0301479712001302

Wheaton, J. M., Brasington, J., Darby, S. E., Sear, D. A., 2010. Accounting for uncertainty in dems from repeat topographic surveys: improved sediment budgets. Earth Surface Processes and Landforms 35 (2), 136-156.

Wyżga, B., 2007. 20 a review on channel incision in the polish carpathian rivers during the 20th century. In: Habersack, H., Piégay, H., Rinaldi, M. (Eds.), Gravel-Bed Rivers VI: From Process Understanding to River Restoration. Vol. 11 of Developments in Earth Surface Processes. Elsevier, pp. 525 - 553. URL http://www.sciencedirect.com/science/article/pii/ S0928202507111421

Wyżga, B., Zawiejska, J., Radecki-Pawlik, A., 2016. Impact of channel incision on the hydraulics of flood flows: Examples from polish carpathian rivers. Geomorphology 272 (Supplement C), 10 - 20, floods in Mountain Environments.

URL http://www.sciencedirect.com/science/article/pii/ S0169555X15300015 
Zanoni, L., Gurnell, A., Drake, N., Surian, N., 2008. Island dynamics in a braided river from analysis of historical maps and air photographs. River Research and Applications 24 (8), 1141-1159.

URL http://dx.doi.org/10.1002/rra.1086

Zawiejska, J., Wyżga, B., Radecki-Pawlik, A., 2015. Variation in surface bed material along a mountain river modified by gravel extraction and channelization, the czarny dunajec, polish carpathians. Geomorphology 231 (Supplement C), $353-366$.

URL http://www.sciencedirect.com/science/article/pii/ S0169555X14006308

Ziliani, L., Surian, N., 2012. Evolutionary trajectory of channel morphology and controlling factors in a large gravel-bed river. Geomorphology 173174 (Supplement C), $104-117$.

URL http://www.sciencedirect.com/science/article/pii/ S0169555X12002723 